\title{
Evaluation of Sewage-Sludge, Zinc, Boron and Sulphur Application for Increasing Productivity and quality of Mustard (Brassica juncea L.) in an Inceptisol
}

\author{
Neelam Yadav ${ }^{1 *}$, S.K. Singh ${ }^{1}, \operatorname{Roshan}_{\text {Kumawat }}{ }^{2}$ and Karishma $\operatorname{Yadav}^{2}$ \\ ${ }^{1}$ Institute of Agricultural Sciences, Banaras Hindu University, Varanasi, India \\ ${ }^{2}$ SKN College of Agriculture (SKNAU), Jobner, Rajasthan \\ *Corresponding author
}

\begin{tabular}{|l|}
\hline K e y w o r d s \\
Mustard, Sewage- \\
$\begin{array}{l}\text { Sludge, Oil content, } \\
\text { Crop productivity, } \\
\text { Boron, Sulphur and } \\
\text { Zinc }\end{array}$ \\
\hline Article Info \\
\hline $\begin{array}{l}\text { Accepted: } \\
\text { 06 July 2018 } \\
\text { Available Online: } \\
\text { 10 August } 2018\end{array}$ \\
\hline
\end{tabular}

\section{Introduction}

Indian mustard (Brassica juncea L.), is one of the important winter season edible oilseed crop of country. The estimated area, production and productivity of rapeseedmustard in the world is $34.19 \mathrm{M}$ ha, $63.09 \mathrm{MT}$ and $1,850 \mathrm{~kg} \mathrm{ha}^{-1}$, respectively (FAO, 2016). India accounts for $19.29 \%$ and $10.07 \%$ of the total acreage and production of rapeseed and mustard (FAO, 2015). The mustard is predominantly cultivated in the states of Rajasthan, U.P., Haryana, M.P., Gujarat, Punjab and Bihar. The mustard growing areas in India are experiencing the vast diversity in the agro climatic conditions. Effective management of natural resources, integrated approach to plant-water, nutrient and pest 
management and extension of rapeseedmustard cultivation to newer areas under different cropping systems will play a key role in further increasing and stabilizing the productivity and production of rapeseedmustard. Nutrient management stands among the most crucial factors in crop production. Exploitation of genetic yield potential of any new plant type depends on availability of all essential nutrients in balanced and optimum amounts. It has been noticed that intensive cultivation of modern crop varieties through application of higher doses of NPK fertilizers have increased the crop yields mining out the inherent micronutrients from soils.

Keeping in view the ever increasing demand of oilseed production of the country, there is a need to maintain adequate supply of nutrients through organic and inorganic sources or both (Yadav et al., 2017). It has been observed in the earlier studies that sewage-sludge contains a considerable amount of micronutrients particularly $\mathrm{Zn}, \mathrm{Fe}, \mathrm{Cu}$ and $\mathrm{Mn}$. The application of sewage sludge (SS) as a source of plant nutrients and soil conditioner is increasingly being favoured by the farmers not only in our country but across the globe. The total sewage generated from urban areas was estimated 62,000 million litres per day (MLD), while the treatment capacity across India is only 23,277 MLD, or $37 \%$ of sewage generated (Golui et al., 2014). Sewage sludge is a mixture of liquid-solid residue resulting from the treatment of urban or industrial effluents. It can be considered as a viable alternative for fertilizer and soil conditioner. Sewage sludge is a good source of micro/macronutrients and also rich in organic matter (Zoubi et al., 2008; Golui et al., 2014). Addition of sludge to agricultural soil is associated with recycling of important major plant nutrients such as N, P, K and S (Kumar et al., 2006; Martinez et al., 2002). More importantly, these waste materials add substantial amount of organic matter, besides improving physical properties of soil like bulk density, porosity, water holding capacity, hydraulic conductivity, infiltration rate, water holding capacity of soil and aggregate stability (Singh and Agrawal, 2008). The presence of humic substances in sewage sludge will also affect cation exchange capacity (CEC) and thus affect nutrient retaining capacity of the soil. Further, application of sludge is capable of reclamation of acid and sodic soil. Improvements in soil health and consequent positive responses have been reported in various crops, viz. sunflower (Morera et al., 2013), wheat (Khan et al., 2007), maize (Zoubi et al., 2008), rice-wheat (Latare and Singh, 2013; Latare et al., 2014; Latare et al., 2017). Though, the sewage sludge is very rich in organic matter and nutrients. Yet, the information on impact of sewage sludge on crop productivity and soil health including nutrients availability, their uptake by plants and accumulation of heavy metals are scanty. Keeping these facts into consideration, the present investigation was planned to study the effect of sulphur, zinc, boron and sewage sludge application on growth and yield of mustard.

\section{Materials and Methods}

The investigation was carried out in a pot experiment under net house at the Department of Soil Science and Agricultural Chemistry, Institute of Agricultural Sciences, Banaras Hindu University, Varanasi, U.P. (India).The study site located in the western bank of river Ganges, Varanasi is situated at an altitude of 80.71 meters above mean sea level and located between $25^{\circ} 19^{\prime}$ North latitude and $83^{\circ} 10^{\prime}$ East longitudes. The soils of Varanasi are formed on alluvium deposited by the river Ganges and have predominance of illite, quartz and feldspars minerals. The alluvial soil is characterized by higher silt content. Illitic nature of alluvial sediments is clearly demonstrated by higher $\mathrm{K}_{2} \mathrm{O}$ content. The 
cropping history of the site from where the soil was collected is the maize-wheat. The fertility status of the soil is classed as low to medium with a slightly alkaline reaction.

Glazed pots having $10 \mathrm{~kg}$ capacity were taken, labelled and filled with $10 \mathrm{~kg}$ of processed soil. The whole quantity of soil was placed on a polythene sheet and according to the treatments, the required quantities of sewage sludge material was incorporated and mixed thoroughly with the soil. The recommended dose of fertilizer (RDF) for mustard (Brassica sp.) was $\mathrm{N}: \mathrm{P}_{2} \mathrm{O}_{5}: \mathrm{K}_{2} \mathrm{O}:: 80: 40: 40 \mathrm{~kg} \mathrm{ha}^{-1}$. To supply the recommended dose of fertilizer, a nutrient solution was prepared which supplied $40 \mathrm{mg} \mathrm{N}, 20 \mathrm{mg} \mathrm{P}_{2} \mathrm{O}_{5}$ and $20 \mathrm{mg} \mathrm{K}_{2} \mathrm{O} \mathrm{kg}^{-1}$ soil. The nutrient solution was prepared using urea as $\mathrm{N}$ source, analytical grade Diammonium phosphate (DAP) as the source of phosphorus and potassium chloride $(\mathrm{KCl})$ as the source of potassium. Water was added to the soil samples to raise the moisture content to $50 \%$ of the field capacity. The moist samples were then transferred in the pots and kept in the greenhouse. Altogether twelve treatments consisted of combinations of sewage sludge and chemical fertilizers, $\mathrm{S}$, $\mathrm{Zn}$, B, along with a control were used for pot experiments.

The experiment was laid out in a completely randomized design (CRD) with three replications. The treatments detailed are given below: $\mathrm{T}_{1}-$ Absolute Control (No fertilizer), $\mathrm{T}_{2}$ - Control (100\% RDF), $\mathrm{T}_{3}-100 \% \mathrm{RDF}+\mathrm{S}$ @ $30 \mathrm{~kg} \mathrm{ha}^{-1}, \mathrm{~T}_{4^{-}} 100 \% \mathrm{RDF}+\mathrm{B} @ 1.5 \mathrm{~kg}$ $\mathrm{ha}^{-1}, \mathrm{~T}_{5^{-}} 100 \% \mathrm{RDF}+\mathrm{Zn} @ 5 \mathrm{~kg} \mathrm{ha}{ }^{-1}, \mathrm{~T}_{6^{-}}$ $100 \% \mathrm{RDF}+\mathrm{S} @ 30 \mathrm{~kg} \mathrm{ha}^{-1}+\mathrm{B} @ 1.5 \mathrm{~kg} \mathrm{ha}^{-}$ 1, $\mathrm{T}_{7^{-}} 100 \% \mathrm{RDF}+\mathrm{Zn} @ 5 \mathrm{~kg} \mathrm{ha}^{-1}+\mathrm{B} @ 1.5$ $\mathrm{kg} \mathrm{ha}^{-1}, \mathrm{~T}_{8^{-}} 100 \% \mathrm{RDF}+\mathrm{S} @ 30 \mathrm{~kg} \mathrm{ha}^{-1}+\mathrm{Zn}$ @ $5 \mathrm{~kg} \mathrm{ha}^{-1}+\mathrm{B} @ 1.5 \mathrm{~kg} \mathrm{ha}^{-1}, \mathrm{~T}_{9^{-}} 100 \% \mathrm{RDF}$ +Sewage Sludge@10 tha ${ }^{-1}, \mathrm{~T}_{10}-100 \%$ RDF + sewage Sludge @ $20 \mathrm{t} \mathrm{ha}^{-1}, \mathrm{~T}_{11^{-}} 75 \% \mathrm{RDF}+$ Sewage Sludge @ $10 \mathrm{t} \mathrm{ha}^{-1}, \mathrm{~T}_{12}-75 \% \mathrm{RDF}+$ Sewage Sludge@ $20 \mathrm{tha}^{-1}$
The seeds of mustard were sown on $10^{\text {th }}$ November, 2016. Forty seeds were sown in each pot and the upper layer was moistened with water to ensure proper germination. After germination of seeds, thinning was done to maintain four plants per pot. The plants were maintained in the pot culture and care was taken to ensure proper growth. Irrigation was given as and when required. The growth and yield attributes were estimated as per the standard procedure by sampling from three places in each plot. Greenness Index of mustard plants was measured at 90 days after sowing with SPAD meter. At maturity, the plants were harvested and seeds were separated from the plant, kept in paper bags and dried in hot air oven at $60 \pm 2{ }^{\circ} \mathrm{C}$ till the weight became constant and seed yield ( $\mathrm{g} \mathrm{pot}^{-}$ $\left.{ }^{1}\right)$ was computed. After harvesting of crop, seeds were separated and plant samples were kept in paper bags, dried in hot air oven at 60 $\pm 2{ }^{\circ} \mathrm{C}$ till the weight became constant and stover yield $\left(\mathrm{g}\right.$ pot $\left.^{-1}\right)$ was recorded. The harvest index was calculated by using the following formula:

$$
\text { Harvest Index }(\%)=\frac{\text { Economic yield }\left(\mathrm{q} \mathrm{ha}^{-1}\right)}{\text { Biological yield }\left(\mathrm{q} \mathrm{ha}^{-1}\right)}
$$

\section{Results and Discussion}

\section{Plant height}

Data pertaining to plant height is given in Table 1. It is evident from the data that significant increase in plant height (30 DAS) was recorded with the application of $\mathrm{B}, \mathrm{Zn}, \mathrm{S}$ and sludge. The maximum plant height was observed in treatment T10 (100\% RDF + SS $20 \mathrm{t} \mathrm{ha}^{-1}$ ) followed by T12 (75\% RDF+ SS 20 $\mathrm{t} \mathrm{ha}^{-1}$ ) but both treatment were at par to each other at all the growth stage $(30,60,90 \mathrm{DAS})$. Sludge application in T10 and T12 caused an increase in plant height by 73.11 and $60.40 \%$, respectively over control (T2). Application of 
zinc, boron and sulphur caused a significant increase in plant height in T8 $(100 \% \mathrm{RDF}+\mathrm{S}$ $30 \mathrm{~kg} \mathrm{ha}^{-1}+\mathrm{Zn} 5 \mathrm{~kg} \mathrm{ha}^{-1}+\mathrm{B} 15 \mathrm{~kg} \mathrm{ha}^{-1}$ ) over absolute control $\left(\mathrm{T}_{1}\right)$ and control $\left(\mathrm{T}_{2} 100 \%\right.$ RDF).Almost similar trend was reported was noticed with the plant height at 60 and 90 DAS except a slight increase in plant height as compared to observations recorded at 30DAS.

Also individual application of sewage sludge and fertilizers were found to be statistically significant. The optimum availability of macro and micro nutrients with integrated use of sludge (Yamur et al., 2005) and inorganic nutrient sources might improve source system of plant and also increases its efficiency for enhanced photosynthesis leading to higher plant height. The observed trends is in agreeing with the findings of Naser and Islam (2001), Piri and Sharma (2006). Moreover, favourable effect of optimum level of nutrients (Zn, B and S) through their application along with recommended dose of fertilizers might improve the leaf area which improve sinksource relationship could be one of the reasons for higher plant height and growth of mustard.

\section{Number of leaves plant ${ }^{-1}$}

Data pertaining to Number of leaves ${ }^{\mathbf{- 1}}$ have been presented in Table 2. The number of leaves ranged from 7.70 to 14.53 at 60 DAS. Highest number of leaves obtained in T10 followed by in T12 which is 14.53 and 13.97, respectively. The optimal and balanced supply of macro and micronutrient and their higher uptake with combined use of nutrient inputs such as sludge and inorganic might results in plant growth, dry matter accumulation and ultimately higher number of leaves compared to no application of fertilization and when chemical fertilizer applied alone. Similar results were also reported by many other researchers which state that integration of sludge and in-organic sources led to higher leaf growth and development (Kumar and
Yadav, 2007). Moreover, as we know that nitrogen, boron, zinc and sulphur are the chief constituent of many of the lipids and nucleoproteins, and an optimum supply of these in the plants with their application along with recommended dose of fertilizer might have helped in higher cell division and multiplication which ultimately led to better leaf growth of mustard and boosted plant growth (Kumar and Kumar, 2007).

\section{Number of primary branches plant ${ }^{-1}$}

Data pertaining to primary branches have been presented in Table 2. The number of primary branches of mustard crop increased significantly from $\mathrm{T} 1$ to $\mathrm{T} 12$. The number of primary branches ranged from 2.66-4.87 at 90 DAS. The maximum number of primary branches i.e.4.87 was recorded with treatment T10 followed by T12 with 4.47 at 90DAS, which was 35.75 and $24.86 \%$ higher over T2 (control). The minimum number of primary branches i.e. 2.66 and 3.58 was reported in $\mathrm{T} 1$ and $\mathrm{T} 2$, respectively.

The increase in number of primary branches might be due to quick availability of boron, zinc and sulphur during entire growing season. Combined application of nutrient inputs from inorganic fertilizers and sludge might improve the source capacity and photosynthetic rate of the plants which is of fundamental importance for optimum plant growth therefore led to higher dry matter accumulation and number of branches with the combined application of sludge and inorganic fertilization including boron, sulphur and zinc compared to when chemical fertilizer applied alone or no fertilization. Similar results were also reported by many other researchers which reported that integration of chemical fertilization and sludge, zinc, boron and sulphur led to higher crop growth of mustard (Kumar and Kumar, 2007; Patel and Ghosh, 2013; Yadav et al., 2016). 


\section{Greenness index}

Data pertaining to greenness index of leaves as influenced by different levels of zinc, boron, sulphur and sludge applications is presented in Table 2. All treatments showed significant increase in SPAD value over control (T2). The maximum SPAD value was recorded in T10 followed by T8, which showed an increase of 30.99 and $25.35 \%$, respectively over control. The lowest value was observed in T1 (absolute control) followed by T2 (control). The application of Boron with zinc and sulphur combination in $\mathrm{T} 4, \mathrm{~T} 6, \mathrm{~T} 7$, and $\mathrm{T} 8$ increased greenness index but $\mathrm{T} 4$ and $\mathrm{T} 6$ were statistically at par with each other similarly with the T6, T7 and T8. An optimum nutrient supply particularly $\mathrm{N}$ throughout the growing season with use of sludge and inorganic fertilization might improve leaf growth rate and its nitrogen content which led to higher chlorophyll content. Moreover, optimum supply of zinc, boron and sulphur with their application along with recommended dose of fertilizer might improved availability, uptake and utilization of $\mathrm{N}$ by crop is one of the reason for higher values of greenness index with compared to control and RDF alone.

Similar results of higher chlorophyll content were also reported by Singh and Agrawal, (2007) for integrated use of sludge and inorganic fertilization, Thapa (2006) for zinc, Singh and Singh (2005) for sulphur, Latare and Singh (2013) for sewage sludge.

Table.1 Effect of sulphur, zinc, boron and sewage sludge application on plant height of mustard

\begin{tabular}{|l|l|l|l|}
\hline \multirow{2}{*}{ Treatments } & \multicolumn{3}{|c|}{ Plant Height $(\mathrm{cm})$} \\
\cline { 2 - 4 } & 30DAS & $60 \mathrm{DAS}$ & $90 \mathrm{DAS}$ \\
\hline T1 & $12.30 \mathrm{~g}$ & $40.01 \mathrm{i}$ & $104.60 \mathrm{~h}$ \\
\hline T2 & $14.17 \mathrm{f}$ & $44.60 \mathrm{hi}$ & $118.17 \mathrm{~g}$ \\
\hline T3 & $17.93 \mathrm{de}$ & $54.37 \mathrm{ef}$ & $137.02 \mathrm{def}$ \\
\hline T4 & $15.00 \mathrm{f}$ & $49.07 \mathrm{gh}$ & $131.17 \mathrm{f}$ \\
\hline T5 & $16.90 \mathrm{e}$ & $50.07 \mathrm{fg}$ & $133.72 \mathrm{ef}$ \\
\hline T6 & $19.47 \mathrm{~cd}$ & $57.53 \mathrm{de}$ & $144.23 \mathrm{bcde}$ \\
\hline T7 & $19.87 \mathrm{c}$ & $57.33 \mathrm{de}$ & $141.53 \mathrm{cdef}$ \\
\hline T8 & $22.57 \mathrm{~b}$ & $66.73 \mathrm{ab}$ & $154.70 \mathrm{ab}$ \\
\hline T9 & $21.73 \mathrm{~b}$ & $62.80 \mathrm{bc}$ & $151.00 \mathrm{bc}$ \\
\hline T10 & $24.53 \mathrm{a}$ & $71.13 \mathrm{a}$ & $165.67 \mathrm{a}$ \\
\hline T11 & $21.17 \mathrm{bc}$ & $61.60 \mathrm{~cd}$ & $147.87 \mathrm{bcd}$ \\
\hline T12 & $22.73 \mathrm{ab}$ & $67.57 \mathrm{ab}$ & $156.03 \mathrm{ab}$ \\
\hline CV (\%) & 5.70 & 5.20 & 5.37 \\
\hline
\end{tabular}

Different letters for each parameters show significant different at $\mathrm{p}<0.05$. T1: Absolute Control (No fertilizer), T2: Control (100\% RDF), T3:100\% RDF+ S $30 \mathrm{~kg} \mathrm{ha}^{-1}$ T4:100\% RDF+ B $1.5 \mathrm{~kg} \mathrm{ha}^{-1}$, T5: 100\% RDF+Zn $5 \mathrm{~kg} \mathrm{ha}^{-1}$, T6:100\%RDF+ S $30 \mathrm{~kg} \mathrm{ha}^{-1}+\mathrm{B} 1.5 \mathrm{~kg} \mathrm{ha}^{-1}, \mathrm{~T} 7: 100 \% \mathrm{RDF}+\mathrm{Zn} 5 \mathrm{~kg} \mathrm{ha}^{-1}+\mathrm{B} 1.5 \mathrm{~kg} \mathrm{ha}^{-1}, \mathrm{~T} 8: 100 \% \mathrm{RDF}+\mathrm{S} 30 \mathrm{~kg}$ $\mathrm{ha}^{-1}+\mathrm{Zn} 5 \mathrm{~kg} \mathrm{ha}^{-1}+\mathrm{B} 1.5 \mathrm{~kg} \mathrm{ha}^{-1}$, T9: 100\% RDF+ SS $10 \mathrm{t} \mathrm{ha}^{-1}$, T10: $100 \% \mathrm{RDF}+\mathrm{SS} 20 \mathrm{tha}^{-1}, \mathrm{~T} 11: 75 \% \mathrm{RDF}+\mathrm{SS}$ $10 \mathrm{tha}^{-1}$, T12: $75 \%$ RDF+ SS $20 \mathrm{tha}^{-1}$ 
Table.2 Effect of sulphur, zinc, boron and sewage sludge application on growth parameters (number of leaves, number of branches, greenness index) of mustard

\begin{tabular}{|l|c|c|c|}
\hline \multirow{2}{*}{ Treatments } & Number of Leaves plant-1 & Number of Branches plant-1 & $\begin{array}{c}\text { Greenness } \\
\text { Index (SPAD) }\end{array}$ \\
\cline { 2 - 3 } & 60DAS & $90 \mathrm{DAS}$ & $1.32 \mathrm{f}$ \\
\hline T1 & $7.70 \mathrm{~h}$ & $2.66 \mathrm{f}$ & $1.42 \mathrm{ef}$ \\
\hline T3 & $8.67 \mathrm{~h}$ & $3.58 \mathrm{e}$ & $1.58 \mathrm{~cd}$ \\
\hline T4 & $10.63 \mathrm{fg}$ & $3.86 \mathrm{de}$ & $1.50 \mathrm{de}$ \\
\hline T5 & $9.73 \mathrm{~g}$ & $3.61 \mathrm{e}$ & $1.52 \mathrm{de}$ \\
\hline T6 & $10.07 \mathrm{~g}$ & $3.55 \mathrm{e}$ & $1.64 \mathrm{bcd}$ \\
\hline T7 & $11.63 \mathrm{de}$ & $4.08 \mathrm{bcd}$ & $1.70 \mathrm{bc}$ \\
\hline T8 & $11.47 \mathrm{ef}$ & $4.04 \mathrm{~cd}$ & $1.78 \mathrm{ab}$ \\
\hline T9 & $13.43 \mathrm{bc}$ & $4.37 \mathrm{bc}$ & $1.76 \mathrm{ab}$ \\
\hline T10 & $12.93 \mathrm{c}$ & $4.28 \mathrm{bcd}$ & $1.74 \mathrm{ab}$ \\
\hline T11 & $14.53 \mathrm{a}$ & $4.87 \mathrm{a}$ & $1.56 \mathrm{cde}$ \\
\hline T12 & $12.50 \mathrm{~cd}$ & $4.17 \mathrm{bcd}$ & 5.36 \\
\hline CV $(\%)$ & $13.97 \mathrm{ab}$ & $4.47 \mathrm{ab}$ & 6.31 \\
\hline
\end{tabular}

Different letters for each parameters show significant different at $\mathrm{p}<0.05$. T1: Absolute Control (No fertilizer), T2: Control (100\% RDF), T3:100\% RDF+ S $30 \mathrm{~kg} \mathrm{ha}^{-1,} \mathrm{~T} 4: 100 \% \mathrm{RDF}+\mathrm{B} 1.5 \mathrm{~kg} \mathrm{ha}^{-1}$, T5: 100\% RDF+Zn $5 \mathrm{~kg} \mathrm{ha}^{-1}$, T6:100\%RDF+ S $30 \mathrm{~kg} \mathrm{ha}^{-1}+\mathrm{B} 1.5 \mathrm{~kg} \mathrm{ha}^{-1}, \mathrm{~T} 7: 100 \% \mathrm{RDF}+\mathrm{Zn} 5 \mathrm{~kg} \mathrm{ha}^{-1}+\mathrm{B} 1.5 \mathrm{~kg} \mathrm{ha}^{-1}, \mathrm{~T} 8: 100 \% \mathrm{RDF}+\mathrm{S} 30 \mathrm{~kg}$ $\mathrm{ha}^{-1}+\mathrm{Zn} 5 \mathrm{~kg} \mathrm{ha}^{-1}+\mathrm{B} 1.5 \mathrm{~kg} \mathrm{ha}^{-1}$, T9: 100\% RDF+ SS $10 \mathrm{t} \mathrm{ha}^{-1}$, T10: 100\% RDF+ SS $20 \mathrm{tha}^{-1}$, T11: 75\% RDF+ SS $10 \mathrm{tha}^{-1}, \mathrm{~T} 12: 75 \% \mathrm{RDF}+\mathrm{SS} 20 \mathrm{tha}^{-1}$

Table.3 Effect of sulphur, zinc, boron and sewage sludge application on seed yield, stover yield and oil content

\begin{tabular}{|l|c|c|c|}
\hline Treatments & $\begin{array}{c}\text { Seed Yield } \\
(\mathrm{g} \text { pot-1) }\end{array}$ & $\begin{array}{c}\text { Stover Yield } \\
(\mathrm{g} \text { pot-1) }\end{array}$ & Oil Content (\%) \\
\hline T1 & $11.43 \mathrm{~g}$ & $35.70 \mathrm{~g}$ & $34.40 \mathrm{a}$ \\
\hline T2 & $13.30 \mathrm{f}$ & $42.37 \mathrm{f}$ & $36.53 \mathrm{a}$ \\
\hline T3 & $16.43 \mathrm{de}$ & $48.18 \mathrm{de}$ & $37.59 \mathrm{a}$ \\
\hline T4 & $14.87 \mathrm{ef}$ & $46.46 \mathrm{e}$ & $36.73 \mathrm{a}$ \\
\hline T5 & $14.93 \mathrm{ef}$ & $47.24 \mathrm{e}$ & $36.83 \mathrm{a}$ \\
\hline T6 & $16.97 \mathrm{~cd}$ & $50.72 \mathrm{~cd}$ & $38.47 \mathrm{a}$ \\
\hline T7 & $16.63 \mathrm{~cd}$ & $49.53 \mathrm{cde}$ & $37.93 \mathrm{a}$ \\
\hline T8 & $18.97 \mathrm{~b}$ & $54.67 \mathrm{~b}$ & $39.12 \mathrm{a}$ \\
\hline T9 & $18.20 \mathrm{bc}$ & $54.17 \mathrm{~b}$ & $38.94 \mathrm{a}$ \\
\hline T10 & $20.90 \mathrm{a}$ & $60.49 \mathrm{a}$ & $40.37 \mathrm{a}$ \\
\hline T11 & $17.53 \mathrm{bcd}$ & $52.90 \mathrm{bc}$ & $38.79 \mathrm{a}$ \\
\hline T12 & $19.13 \mathrm{~b}$ & $55.82 \mathrm{~b}$ & $40.10 \mathrm{a}$ \\
\hline CV $(\%)$ & 6.01 & 4.06 & 5.20 \\
\hline
\end{tabular}

Different letters for each parameters show significant different at $\mathrm{p}<0.05$. T1: Absolute Control (No fertilizer), T2: Control (100\% RDF), T3:100\% RDF+ S $30 \mathrm{~kg} \mathrm{ha}^{-1,} \mathrm{~T} 4: 100 \% \mathrm{RDF}+\mathrm{B} 1.5 \mathrm{~kg} \mathrm{ha}^{-1}$, T5: 100\% RDF+Zn $5 \mathrm{~kg} \mathrm{ha}^{-1}$, T6:100\%RDF+ S $30 \mathrm{~kg} \mathrm{ha}^{-1}+\mathrm{B} 1.5 \mathrm{~kg} \mathrm{ha}^{-1}, \mathrm{~T} 7: 100 \% \mathrm{RDF}+\mathrm{Zn} 5 \mathrm{~kg} \mathrm{ha}^{-1}+\mathrm{B} 1.5 \mathrm{~kg} \mathrm{ha}^{-1}, \mathrm{~T} 8: 100 \% \mathrm{RDF}+\mathrm{S} 30 \mathrm{~kg}$ $\mathrm{ha}^{-1}+\mathrm{Zn} 5 \mathrm{~kg} \mathrm{ha}^{-1}+\mathrm{B} 1.5 \mathrm{~kg} \mathrm{ha}^{-1}$, T9: 100\% RDF+ SS $10 \mathrm{t} \mathrm{ha}^{-1}, \mathrm{~T} 10: 100 \% \mathrm{RDF}+\mathrm{SS} 20 \mathrm{t} \mathrm{ha}^{-1}, \mathrm{~T} 11: 75 \% \mathrm{RDF}+\mathrm{SS}$ $10 \mathrm{tha}^{-1}, \mathrm{~T} 12: 75 \%$ RDF+ SS $20 \mathrm{tha}^{-1}$ 


\section{Seed and stover yield ( $\left.\mathrm{g} \mathrm{pot}^{-1}\right)$}

Data pertaining to seed yield have been presented in Table 3 which clearly showed that seed yield of mustard as influenced with the application of varying levels of boron, zinc, sulphur and sludge. The maximum seeds yield was found in treatment $\mathrm{T} 10$ followed by T12 with 20.90 and $19.13 \mathrm{~g} \mathrm{pot}^{-1}$, respectively but both these are statistically at par with each other. The minimum seeds yield was found in absolute control (T1). The treatments in which B was applied alone and in combination with the sulphur and zinc show a significant increase in seed yield. Thus boron applied with the combination of sulphur and zinc is more effective to produce more seeds yield then alone application of boron. The treatments $\mathrm{T} 8$ shows significant increase over T4, T6 and T7. The treatments T6 and T7 are not significant with each other. A critical perusal of the data presented in Table 3 revealed different levels of zinc, boron, sulphur and sludge application showed significant increase on stover yield, when compared with control (T2). The Stover yield ranged between 35.7-60.5 g $\operatorname{pot}^{-1}$. The maximum stover yield was found in treatment T10, followed by T12 with 60.5 and 55.8, g pot $^{-1}$, respectively but both these are statistically at par with each other. The minimum stover yield was found in absolute control (T1) and control (T2) with 35.7 and $42.4 \mathrm{~g} \mathrm{pot}^{-1}$, respectively.

Insufficient nutrients (macro, secondary and micronutrients) supply throughout the growing season under control and with application of only chemical fertilizer perhaps limited the growth rate and development of crop due to low rate of photosynthesis or insufficient cell expansion or both of these factors. Whereas, optimal and balanced supply of nutrients (macro, secondary and micronutrients) from inorganic sludge along with application of sulphur, zinc and boron led to higher growth and development of plants which ultimately resulted in higher seed and stover yield of mustard compared to control and chemical fertilization alone (Tripathi et al., 2011). Moreover, integrated use of sludge and inorganic fertilizers improved the physical (soil structure and water-holding capacity), chemical (buffering capacity, cation exchange capacity, macro and micro nutrients availability and reduce phosphate fixation) and biological properties of soil (organic matter, soil microbial biomass and soil microorganisms) which further provide an optimum environment for higher growth and development of plants and led to higher yield of crop (Pachauri and Trivedi, 2012; Delgado et al., 2002; Chatha et al., 2002; Indoria et al., (2013). Latare and Singh, (2013) also find out the effect of conjoint application of sewage sludge and fertilizers showed a significant increase in test weight and seed and stover yield, it also supported by Latare et al., (2014).

\section{Oil content in seed}

The data contained in Table 3 showed that oil content in seed increased significantly with varying level of boron, zinc, sulphur and sludge application. Oil content ranges between 34.4-40.4\%. The maximum oil content was found in treatment T10 followed by T12 with 40.4 and $40.1 \%$, respectively but both these are statistically at par with each other. The minimum oil content was found in absolute control (T1) and control (T2) with 34.4 and $36.5 \%$, respectively. Treatment T10 and T8 showed an increase of 10.51 and $9.77 \%$, respectively over control (T2). Sulphur and boron are essential plants nutrients which known for their important and specific role in the synthesis of proteins, chlorophyll and oil. Therefore, optimum and adequate supply of these nutrients with 
combined application of sludge and inorganic fertilization might result in higher oil content compared to control and when chemical fertilizer applied alone (Abid et al., 2014; Yadav et al., 2016). Sahito et al., (2014) also observed that marked improvement in oil content with combined application of sludge and inorganic fertilization.

Keeping in view the ever increasing demand of oilseed production of the country, there is a need to maintain adequate supply of nutrients through organic and inorganic sources, both. In our pot culture study combined application of boron, zinc, sulphur and sewage sludge in mustard crop resulted in significant increase in crop productivity and oil content. Therefore, it can be concluded that due to application of different level of boron, zinc, sulphur and sewage sludge in mustard crop, a significant increase in grain, stover yield and higher oil content can be obtained.

\section{References}

Abid, M., Khan, M.M.H., Kanwal, M. and Sarfraz, M. (2014) Boron application mitigates salinity effects in canola (Brassica napus) under calcareous soil conditions. International Journal of Agriculture and Biology 16, 1165-1170.

Chatha, T. H., Haya, R. and Latif, I. (2002) Influence of sewage sludge and organic manures application on wheat yield and heavy metal availability. Asian Journal of Plant Sciences 1, 79-81.

Delgado, M. A., Farinas, J. C. and Ruano, S. (2002) Firm productivity and export markets: a non-parametric approach. Journal of international Economics 57, 397-422.

FAO, U. (2015) FAO stat. Retrieved Feb, 2015.

FAO, U. (2016) FAO stat. Retrieved Feb, 2016.

Golui, D., Datta, S. P., Rattan, R. K., Dwivedi, B. S. and Meena, M. C. (2014) Predicting bioavailability of metals from sludgeamended soils. Environmental monitoring and assessment 186, 8541-8553.
Indoria, A.K., Poonia, S.R. and Sharma K.L. (2013) Phytoextractability of Cd from Soil by Some Oilseed Species as Affected by Sewage Sludge and Farmyard Manure. Communications in Soil Science and Plant Analysis 44, 3444-3455.

Khan, R.U., Gurmani, A.R., Khan, M.S., LalalUd-Din and Gurmani, A.H. (2011) Residual, direct and cumulative effect of boron application on wheat and rice yield under rice-wheat system. Sarhad Journal of Agriculture 27; 219-223.

Kumar, A. and Kumar, S. (2007) Growth potential of Indian mustard var. Vardan to varying levesl of nitrogen and sulphur. Indian Journal of Agriculture Research 41, 287291.

Kumar, H. and Yadav, D.S. (2007) Effect of phosphorus and sulphur levels on growth, yield and quality of Indian mustard cultivars. Indian Journal of Agronomy 52, 154-157.

Kumar, N., Singh, S. and Singh, V. (2006) Effect of iron and sulphur levels on yield, oil content and their uptake by Indian mustard (Brassica juncea) Indian Journal of Agronomy 51, 63-64.

Latare, A.M. and Singh, S.K. (2013) Effect of sewage sludge and fertilizers application on accumulation of heavy metals and yield of rice (Oryza sativa L.) in an Inceptisol of Varanasi. Journal of the Indian Society of Soil Science 61, 219-225.

Latare, A.M., Kumar, O., Singh, S.K. and Gupta, A. (2014) Direct and residual effect of sewage sludge on yield, heavy metals content and soil fertility under rice-wheat system. Ecological Engineering 69, 17-24.

Latare, A.M., Singh, S.K. and Kumar, O. (2017). Yield and profitability of rice-wheat sequence with conjunctive application of sewage sludge and chemical fertilisers. Indian Journal of Fertilisers 13, 50-61.

Martinez, F., Cuevas, C., Teresa, Walter and Iglesias Ingrid. (2002) Urban organic wastes effects on soil chemical properties in degraded semi-arid ecosystem. In: Seventeenth WCSS, Symposium No. 20, Thailand. Pp. 1-9.

Moreira, R.S., Mincato, R.L. and Santos, B.R. (2013) Heavy metals availability and soil 
fertility after land application of sewage sludge on dystroferric Red Latosol. Science and Agrotecnologia 37, 512-520.

Naser, H.M. and Islam M.R. (2001) Response of mustard to boron fertilization in old Brahmaputra floodplain soil. Pakistan Journal of Biological Sciences 4, 645-48.

Pachauri, R.K. and Trivedi, S.K. (2012) Effect of sulphur levels on growth, yield and quality of Indian mustard (Brassica juncea) genotypes. Annals of Agriculture Research 33, 131-135.

Patel, S.K. and Ghosh, S.K.G. (2013) Effect of different levels of boron and sulphur on growth of chickpea with mustard intercropping system. Trends in Biosciences 6, 188-189.

Piri, I. and Sharma, S.N. (2006).Effect of levels and sources of sulphur on yield attributes, yield and quality of Indian mustard (Brassica juncea).Indian Journal of Agronomy 20, 56-62.

Sahito, H.A., Solangi, A.W., Lanjar, A.G., Solangi, A.H. and Khuhro, S.A. (2014) Effect of micronutrient (zinc) on growth and yield of mustard varieties. Asian Journal of Agriculture and Biology 2, 105113.

Singh, R. P. and Agrawal, M. (2008) Potential benefits and risks of land application of sewage sludge. Waste management 28, 347358.

Singh, S. and Singh, V. (2005) Effect of nitrogen, sulphur and zinc on Indian mustard. Indian Journal of Agriculture Sciences 75, 828-30.

Thapa, Y.R. (2006). Effects of boron and sulphur on yield and oil content of rapeseed grown in sandy loam acid soils of Gunjanagar,
Chitwan. M. Sc. Thesis, Department of Soil Science and Agri. Engeering, IAAS, Rampur, Chitwan, Nepal, pp 74.

Tripathi, M.K., Chaturvedi, S., Shuklaand, D.K. and Saini, S. K. (2011) Influence of integrated nutrient management on growth, yield and quality of Indian mustard (Brassica juncea L.) in Tarai region of northern India. Journal of Crop and Weed7, 104-107.

Yadav, M R; Kumar, R, Parihar, C M, Yadav, R K, Jat, S L, Ram, H, Meena, R K, Singh, M, Birbal, Verma, A P, Kumar, U, Ghosh, A and Jat, M L. 2017b. Strategies for improving nitrogen use efficiency: A review. Agricultural Reviews 38(1):29-41.

Yadav, S.N., Singh, S.K. and Kumar, O. (2016) Effect of boron on yield attributes, seed yield and oil content of mustard (Brassica juncea L.) on an Inceptisol. Journal of the Indian Society of Soil Science 64, 91-296.

Yamur, M., Kaydan, D. and Arvas, O. (2005) Effects of sewage biosolid application on seed protein ratios, seed NP contents, some morphological and yield characters in lentil (Lens culinaris Medic.) Research Journal of Agricluture and Biological Sciences 1, 308-314.

Zoubi, M. M.A., Arslan, A., Abdelgawad, G., Pejon, N., Tabbaa, M. and Jouzdan, O. (2008). The Effect of Sewage Sludge on Productivity of a Crop Rotation of Wheat, Maize and Vetch) and Heavy Metals Accumulation in Soil and Plant in Aleppo Governorate. American-Eurasian Journal of Agriculture and Environmental Science $3,618-625$.

\section{How to cite this article:}

Neelam Yadav, S.K. Singh, Roshan Kumawat and Karishma Yadav. 2018. Evaluation of Sewage-Sludge, Zinc, Boron and Sulphur Application for Increasing Productivity and quality of Mustard (Brassica juncea L.) in an Inceptisol. Int.J.Curr.Microbiol.App.Sci. 7(08): 713-721. doi: https://doi.org/10.20546/ijcmas.2018.708.078 